\title{
Why US Stock Markets Have Recovered So Fast from the Pandemic Crash
}

\author{
Yueyun (Bill) Chen*, Tzu-Ting (Patty) Hsu \\ Department of Business Administration, University of the West, Los Angeles, CA 91770, USA
}

Received July 7, 2021; Revised July 26, 2021; Accepted September 21, 2021

\section{Cite This Paper in the following Citation Styles}

(a): [1] Yueyun (Bill) Chen, Tzu-Ting (Patty) Hsu, "Why US Stock Markets Have Recovered So Fast from the Pandemic Crash," Universal Journal of Accounting and Finance, Vol. 9, No. 5, pp. 972 - 981, 2021. DOI: 10.13189/ujaf.2021.090508.

(b): Yueyun (Bill) Chen, Tzu-Ting (Patty) Hsu (2021). Why US Stock Markets Have Recovered So Fast from the Pandemic Crash. Universal Journal of Accounting and Finance, 9(5), 972 - 981. DOI: 10.13189/ujaf.2021.090508.

Copyright $\mathrm{C} 2021$ by authors, all rights reserved. Authors agree that this article remains permanently open access under the terms of the Creative Commons Attribution License 4.0 International License

\begin{abstract}
This paper focuses on why the US stock markets have recovered so fast from the pandemic crash in March, 2020. It selects three types of the independent variables, the pandemic related variables of the US and global infections and deaths, the economic variables of the jobless claims and economic index, and variables of the vaccines and therapies of the pandemic to study which factors have led to the significant changes of the three US major stock indices (DoW, S \& P 500 and NASDAQ). The regression analyses of the data from March 1 to October 31 , 2020 indicate that it is not the infections or deaths in the US directly and significantly affecting the stock indices, but the vaccines and treatment medicine developments deciding the stock markets movements. In addition, the Weekly Jobless Claims and Weekly Economic Index significantly affected some stock indices. The paper further discusses the prospects of the US stock markets and its long-term threats. This paper is different from other similar studies, using a longer time period of the weekly data (instead of the daily). It also included economic and COVID-19 related medical development variables. It offers a comprehensive and new perspective on the dynamic of the US stock market that is valuable to both investors and policy-makers.
\end{abstract}

Keywords COVID-19, Vaccines, Stock Indices, Stock Market Crash

\section{Introduction}

The effects of the COVID-19 pandemic on the global financial markets and economies are unprecedented. From mid-February to mid-March 2020, major stock indices in the world were down about $30 \%$ or more. On March 12 , many stock indices were decreased by more than $9 \%$. US Dow Jones Industrial Average decreased an additional $10 \%$, following its record set of $7.8 \%$ decrease on March 9. In 10 days from March 9-18, many stock markets triggered 3-4 circuit breakers. The lockdowns of the economies and disruptions of the supply chains caused mass layoffs (Graph 1). Unemployment rates skyrocketed; unemployment rate in many countries was over $10 \%$ and that was $14.7 \%$ in April, 2020 in the US.

However, many stock markets, including the ones in China and US, have recovered very rapidly. Especially, US stock markets have come back extremely fast and its major indices reached historic highs repeatedly (Graph 2 and Graph 3). It is interesting and important to ask why have the US stock markets regained so fast?

There are several explanations for such a speedy recovery. One main reason is that the stock markets foresee the future in the long term. In other words, changes of the stock indices signal the prospects of corporate profits/earnings and the overall economy. 


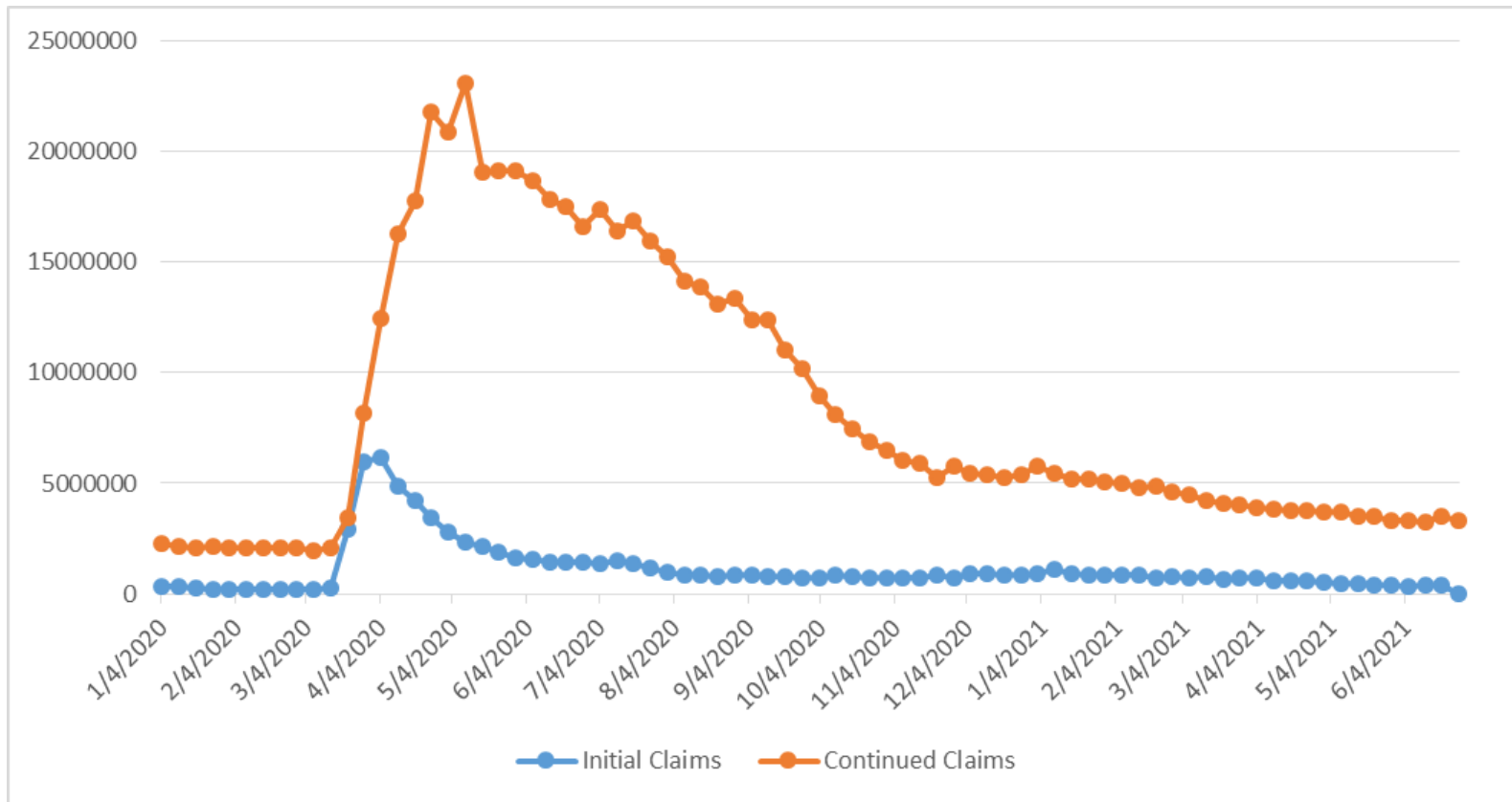

Graph 1. US Weekly Jobless Claims (January 2020 to June 2021)

$40,000.00$

$35,000.00$

$30,000.00$

$25,000.00$

$20,000.00$

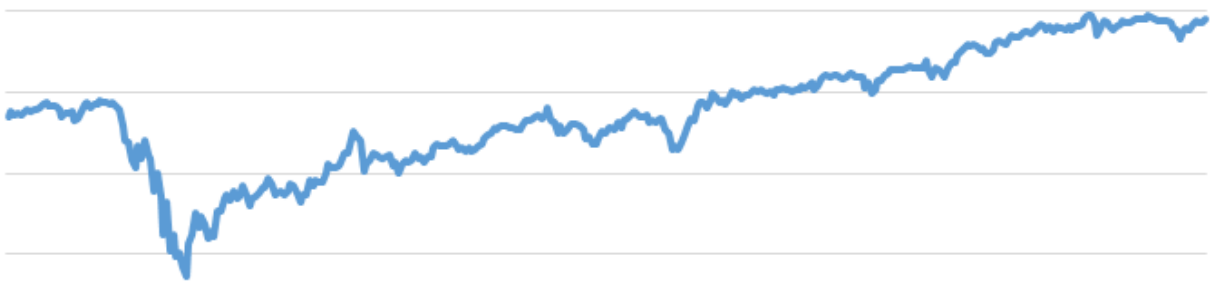

$15,000.00$

$10,000.00$

$5,000.00$

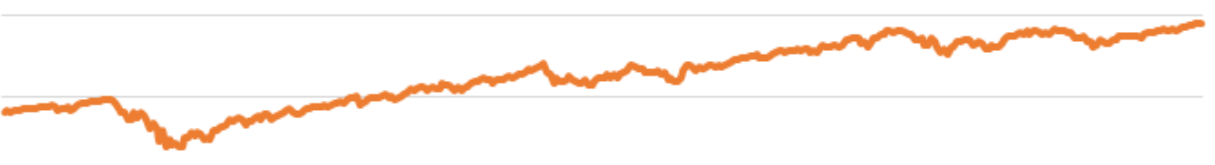

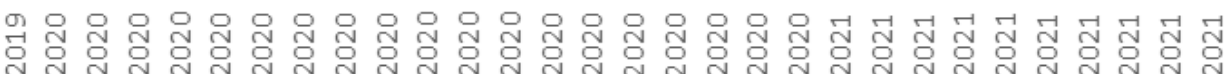
लं

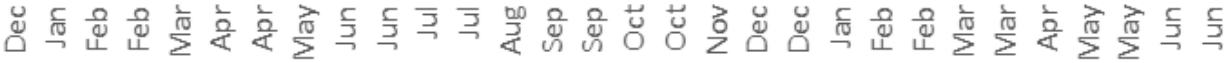

$\longrightarrow$ DOW NASDAQ S\&P 500

Graph 2. US Stock Indices (Daily, January 2020 to June 2021) 


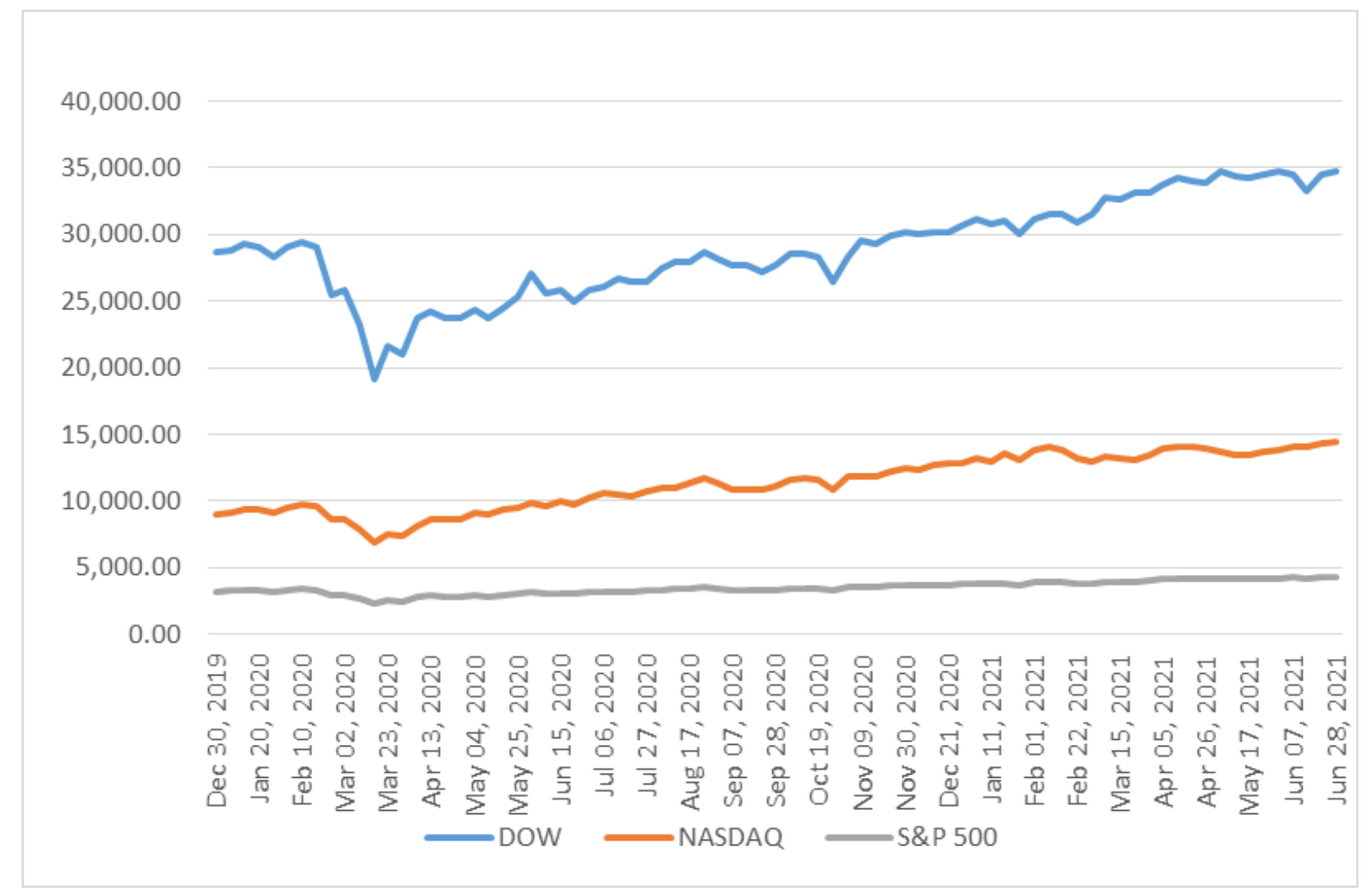

Graph 3. US Stock Indices (Weekly, January 2020 to June 2021)

Efficiency Theory (Berk and Tutarli [7]) states that the current security price reflects the available and relevant information; such information specifically includes the investors' projections of the future economy. Therefore, the current stock prices not only indicate how good or bad these companies or the industries are currently and were in the past, but also reveal what they will be in the future. The second is the short-term supply disruption. The impact of the pandemic on the economy and especially on the supply chain is breathtaking but short-term, so the investors expect the economy will return to the normal soon. David et al. [12] studied the effects of the several pandemics on the stock indices in the US and world and found that such shocks are very short-term generally. The third is the vaccines and therapies of the COVID-19. It is expected that new vaccines and treatment medicines can be developed and used rapidly so that the regular life can be fully resumed. The fourth is the government stimulus and Federal Reserve's firm actions. The US government spent extremely large amount of money to assist individuals, businesses, and public organizations. The Federal Reserve acted strongly and promptly to gain the public's confidence on the US financial systems and its ability to support the economy. There are other possible reasons, including large new small investors like Robinhood investors and the dominance of several large tech stocks in the indices (Banerji [5]).

This paper uses the data of the COVID-19 infections and deaths (Graph 4 \& Graph 5) and other variables--jobless claims, Economic Index and vaccines and therapies of the pandemic to examine which led to recovery of the financial markets. It is different from the previous similar studies. First, it covers the data from March to October, 2020 while other previous studies covered much shorter period. Secondly, weekly data are used, instead of daily since the stock market weekly changes are more stable and logical; the third is the economic variables and COVID-19 related medicine variables are included to better control the other factors. One weakness of using weekly data is the fewer number of samples.

The remaining of the paper is organized as follows: the next section reviews the literature; Section III discusses the econometric model, variables, and data; Section IV presents and explains the regression results; Section V discusses the implications from this study and the long-term threats to the US financial markets; and the last section concludes the paper. 


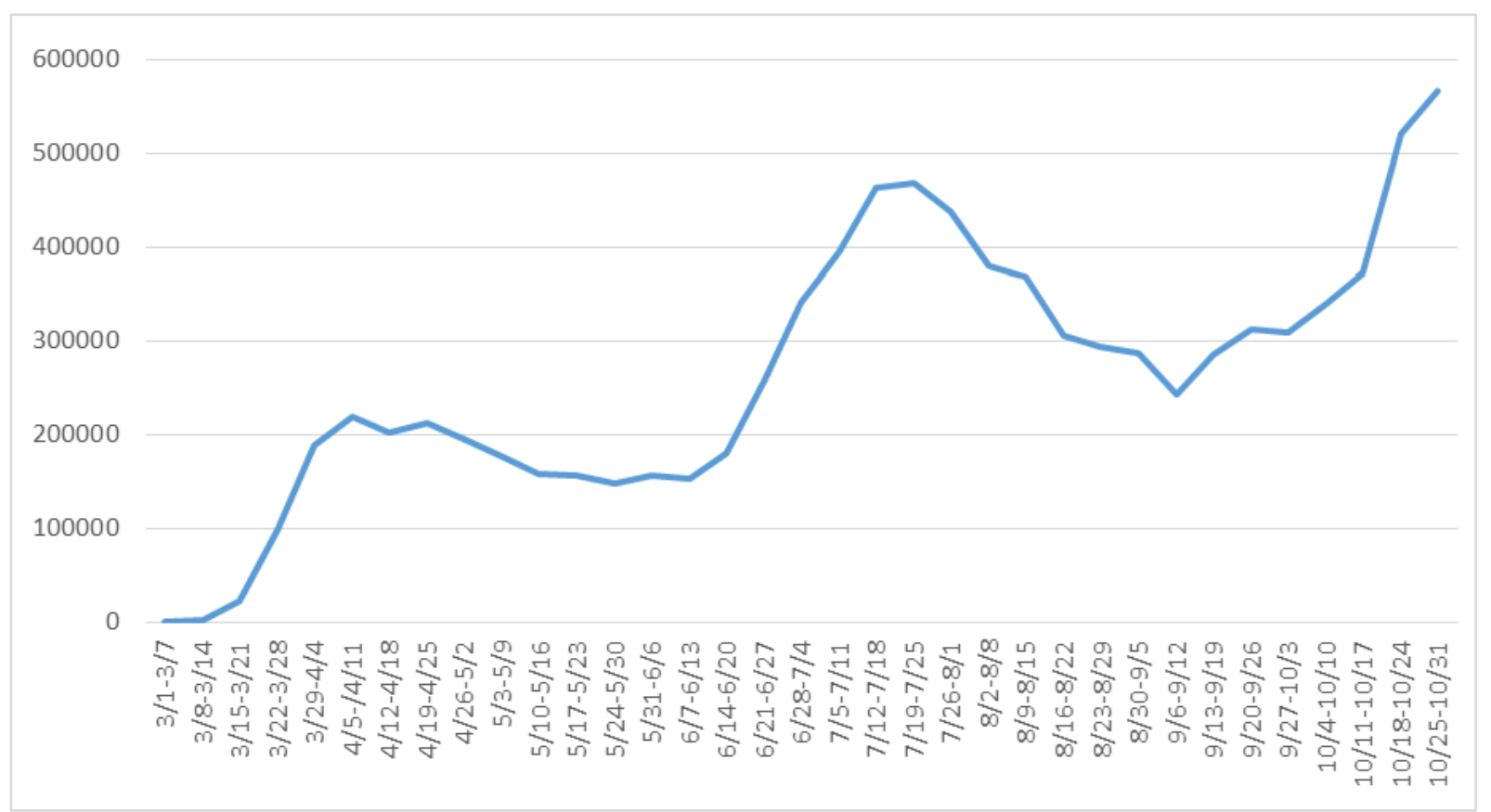

Graph 4. US Weekly New Infections (March to October, 2020)

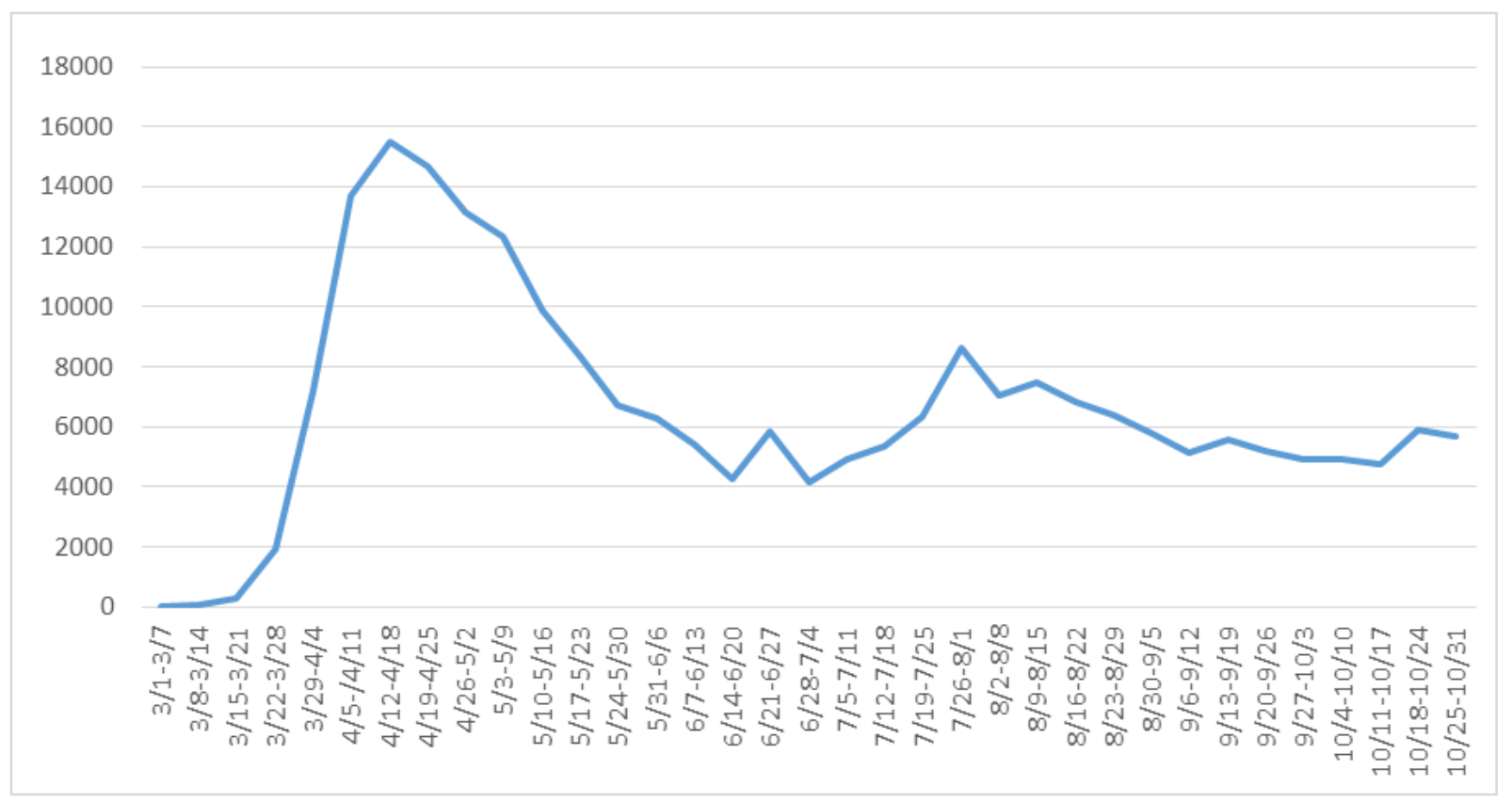

Graph 5. US Weekly New Deaths (March to October 2020)

\section{Review of Literature}

There have been significant amounts of studies on the effects of the pandemic on the society, and especially economies and financial markets. According to Viscusi et al.[24], pneumonia and influenza like SARS and COVID-19 follow cardiovascular disease and cancer ranking as the third leading cause of the probability of death. Barry [6], and Shannon \& Willoughby [23] stated that the fear factor from the "deadliest plague in history- the 1918-19 Spanish influenza affected the global responses to SARS. Hai et al. [14], Siu and Wong [21] and Lee et al. [18] studied the impacts of SARS on the economies of China, Hong Kong and the world. US Congressional Budget Office [11] analyzed effects of influenza pandemic on the US economy and it is concluded that its GDP could be reduced by $1.5 \%-5 \%$ caused by a potential serious virus.

Since the outbreak of COVID-19, there have been studies of its effects on economies and financial markets 
(Yildirim [25], Zhang, et al. [26]). Most studies found out that its impacts on economies and financial markets were more severe on the developing countries than the developed economies because the developed ones have had better healthcare systems and financial resources to deal with this emerging pandemic crisis. Also, the studies indicated that new infection cases had the significant impacts; the new deaths had the significant effects in some studies but were not in the others.

Baig et al. [3] found that the confirmed cases and deaths affected the stock markets' liquidity and volatility. Ashraf [1] stated that using seventy-seven countries data, the government social distancing policy had the direct negative effect on the stock returns due to its impact to the economic activity. Baker et al. [4] used the historical data from 1900 and found out that this COVID 19's impact on the stock markets is more forceful and unprecedented, compared with the previous pandemic, including the Spanish Flu. Salisu et al. [20] compared twenty-four emerging market stocks with the developed markets and it is concluded that the emerging markets are more vulnerable. Harjoto, et al. [15] compared fifty-three emerging stock markets with twenty-three developed ones using the data from January 14 to August 20, 2020 and it is shown that both infection cases and deaths influenced the developing markets returns and volatility but only infection cases affected developed markets returns and volatility. Hasan et al. [17] demonstrated that the response of stock markets to the pandemic is more sensitive than the real economy. The study by David et al. [12] demonstrated that the pandemic shocks significantly affect the stock indices but they were able to recover very fast, just in 79 days on average.

Gherghina and Simionescu [13] used fifteen affected countries data from January 1 to July 23, 2020 and concluded that new cases and deaths negatively impacted most stock market returns. Sharma et al. [22] also examined the data of the fifteen most affected countries from February 1 to May 13, 2020 and showed that after control of other factors, there was a strong relationship between infection cases and stock returns. Haryanto and Mawardi [16] found out the significant impact of COVID-19 news on the performance of Indonesia stock market.

Chahuán-Jiménez et al. [10] demonstrated that the pandemic had less effects on countries with better institutional and economic conditions.

As stated in the previous section, this study has three differences, compared with the other previous studies. The data are from March to October 2020 since the US started reporting the infections and deaths in the first week of March 2020. The data after November 2020 election are not included to avoid the political effects on the stock markets. Adding the economic variables like jobless claims and economic index and COVID-19 related medicine variables like the vaccines and therapies in the regression analyses of the relationship between the pandemic and stock markets should be necessary. That will not only help better control these other effects, but also provide a better and big picture of factors affecting the stock markets and that in turn will be useful to the investors and policy-makers.

\section{The Econometric Model, Variables and Data}

The purpose of this paper is to study the relationship of the COVID-19 and the stock indices. Four types of variables are included. The Dependent Variable is the stock index; the main Independent Variables are the pandemic-related. The third type of variables are medical companies of vaccines and treatments of COVID-19. The last type of the variables are economy-related, including jobless claims and the economic index. Three major indices are used, Dow \&Jones (DoW), S \& P 500 (S\&P) and NASDAQ. The pandemic indicator variables include the new infections and deaths, and cumulative infections and deaths in the US and in the world.

The two types of medical variables are added, the treatment and vaccine of COVID-19. Five medical companies- AbbVie (ABBV), Eli Lilly (LLY), Novartis (NVS), Regeneron (REGN), Gilead(GILD) that are developing the medicines to treat the pandemic and other five companies-BioNTech (BNTX), Glaxo Smith Kline (GSK), Johnson \& Johnson (JNJ), Moderna (MRNA) and Pfizer (PFE) with the vaccines are selected. They could directly affect the stock markets because their drugs under developments will decide whether and how soon the pandemic can be under control. The average prices of these relevant medical stocks are utilized, instead of individual stock prices to avoid the effects of non-pandemic related factors on the individual stocks. These ten pharmaceutical companies are selected based on its reputations and progresses of the relevant medicines during early 2020 . There were no approved medicines yet during that period; the U.S. Food and Drug Administration issued the first emergency use authorization (EUA) for a Pfizer vaccine on December 11, 2020 and approved two more on December 18, 2020 and February 27, 2021.

Among two control variables of the economy, the Jobless Claims are related with the economy and directly affect the financial markets; and the Economic Index is the direct measurement of the whole economy. Weekly data of all variables are used, instead of the daily. Doing so will make it possible to check the effects of these economic variables on the stock markets since there are no daily economic indicators. Also, the weekly data should be more stable and rational in terms of financial markets changes. The Weekly Economic Index(WEI) was developed by Lewis, Mertens and Stock and this is a 
composite index of real economic activity using timely and relevant high-frequency data and represents the common component of ten different daily and weekly series covering consumer behavior, the labor market, and production. Other possible control variables are not included due to the unavailability of the weekly data.

The econometric model is as follows:

Stock Index $($ DoW or S\&P or NASDAQ $)=\mathrm{f}($ Infections, Deaths, Medicines, Jobless, WEI), where $f()$ is the function of its inside variables.

In the above equation, one wants to test which coefficients are significant and especially whether the coefficients of the infections and deaths are significantly negative. One will also reasonably expect that the coefficient of the Weekly Jobless Claims will be negative but the one for the Weekly Economic Index will be positive. In addition, the coefficients of the vaccines and treatment medicines of the COVID-19 would be positive.

The data are from March 1 to October 31, 2020. The weekly values, instead of the daily ones are selected because the weekly stock changes should be more longstanding and rational. Also, some variables such as jobless claims and economic index are only available weekly, not daily. The week of March 1-7 was selected since it was the first week with the COVID 19 infection and death reports in the US. The data after October 31, 2020 was not included due to the concern that the US November election may affect the stock price changes.

The following tables provide the data summaries of the all variables.

Table 1. Data Summary of Economic News and Stock Indexes

\begin{tabular}{|c|c|c|c|c|c|}
\hline & Weekly New Jobless Claims & $\begin{array}{c}\text { Weekly Economic Index } \\
\text { (WEI) }\end{array}$ & DoW & S\&P & NASDAQ \\
\hline Average & $1,904,314$ & $-6.53 \%$ & 25,760 & 3102 & 9,898 \\
\hline Standard Deviation & $1,680,649$ & $3.43 \%$ & 2,292 & 303 & 1,355 \\
\hline
\end{tabular}

Table 2. Data Summary of US and Global COVID-19

\begin{tabular}{|c|c|c|c|c|c|c|c|c|}
\cline { 2 - 8 } \multicolumn{1}{c|}{} & \multicolumn{4}{c|}{ USA } & \multicolumn{4}{c|}{ Global } \\
\hline & $\begin{array}{c}\text { Weekly } \\
\text { new cases }\end{array}$ & $\begin{array}{c}\text { Weekly } \\
\text { new deaths }\end{array}$ & $\begin{array}{c}\text { Total } \\
\text { Infected }\end{array}$ & $\begin{array}{c}\text { Total } \\
\text { deaths }\end{array}$ & $\begin{array}{c}\text { Weekly } \\
\text { new cases }\end{array}$ & $\begin{array}{c}\text { Weekly } \\
\text { new deaths }\end{array}$ & $\begin{array}{c}\text { Total } \\
\text { Infected }\end{array}$ & $\begin{array}{c}\text { Total } \\
\text { deaths }\end{array}$ \\
\hline Average & 263,081 & 6,586 & $3,638,005$ & 123,195 & $1,297,100$ & 33,807 & $15,348,184$ & 546,679 \\
\hline $\begin{array}{c}\text { Standard } \\
\text { Deviation }\end{array}$ & 139,145 & 3,725 & $2,876,975$ & 73,347 & 835,111 & 11,225 & $13,827,190$ & 368,177 \\
\hline
\end{tabular}

Table 3. Data Summary of Medical Stocks

\begin{tabular}{|c|c|c|c|c|c|c|c|c|c|c|c|c|}
\cline { 2 - 14 } \multicolumn{1}{c|}{} & \multicolumn{4}{|c|}{ Treatment Stocks } & \multicolumn{4}{c|}{ Vaccine Stocks } & $\begin{array}{c}1^{\text {1st }} \\
\text { Five }\end{array}$ & $\begin{array}{c}\mathbf{2}^{\text {nd }} \\
\text { Five }\end{array}$ \\
\cline { 2 - 15 } & ABBV & LLY & NVS & REGN & GILD & BNTX & GSK & JNJ & MRNA & PFE & & \\
\hline Average & 86.91 & 148.69 & 85.23 & 571.20 & 69.91 & 61.97 & 38.50 & 142.6 & 59.46 & 33.47 & 192.39 & 67.20 \\
\hline $\begin{array}{c}\text { Standard } \\
\text { Deviation }\end{array}$ & 7.69 & 9.70 & 3.78 & 53.21 & 6.08 & 16.54 & 2.26 & 7.78 & 16.37 & 2.30 & 14.13 & 7.51 \\
\hline
\end{tabular}

Table 4. Model 1 Regression Outcomes

\begin{tabular}{|c|c|c|c|c|c|c|c|c|c|}
\cline { 2 - 10 } \multicolumn{1}{c|}{} & \multicolumn{4}{c|}{ DoW } & \multicolumn{3}{c|}{ S\&P } & \multicolumn{3}{c|}{ NASDAQ } \\
\hline & $\begin{array}{c}\text { Co- } \\
\text { efficients }\end{array}$ & $\boldsymbol{t}$-Stat & $\boldsymbol{P}$-value & $\begin{array}{c}\text { Co- } \\
\text { efficients }\end{array}$ & $\boldsymbol{t}$-Stat & $\boldsymbol{P}$-value & $\begin{array}{c}\text { Co- } \\
\text { efficients }\end{array}$ & $\boldsymbol{t}$-Stat & P-value \\
\hline Intercept & -299.7 & -0.069 & 0.9452 & 29.7922 & 0.0663 & 0.9476 & -1535.22 & -1.062 & 0.2979 \\
\hline $\begin{array}{c}\text { US Weekly } \\
\text { infections }\end{array}$ & -0.0128 & -4.157 & $0.0003^{*}$ & -0.0013 & -4.154 & 0.0003 & -0.0043 & -4.202 & $0.0003^{*}$ \\
\hline US Weekly deaths & 0.178 & 1.4497 & 0.1591 & 0.022 & 1.7182 & 0.0976 & 0.0387 & 0.9411 & 0.3553 \\
\hline $\begin{array}{c}\text { Global Weekly } \\
\text { infections }\end{array}$ & 0.0028 & 3.2125 & $0.0035^{*}$ & 0.0003 & 3.7487 & 0.0009 & 0.0013 & 4.6128 & $0.0001 *$ \\
\hline $\begin{array}{c}\text { Global Weekly } \\
\text { deaths }\end{array}$ & -0.0049 & -0.084 & 0.9334 & -0.0001 & -0.02 & 0.9841 & 0.0103 & 0.5324 & 0.5989 \\
\hline $\begin{array}{c}\text { US Weekly jobless } \\
\text { claims }\end{array}$ & 0.0001 & 0.3687 & 0.7154 & 0 & -0.15 & 0.8816 & -0.0001 & -0.914 & 0.3689 \\
\hline $\begin{array}{c}\text { US Weekly } \\
\text { Economic Index }\end{array}$ & 33504.3 & 2.7267 & $0.0113^{*}$ & 3540.66 & 2.7684 & 0.0102 & 9222.75 & 2.2408 & $0.0338^{* *}$ \\
\hline $\begin{array}{c}\text { Average vaccine } \\
\text { stock price }\end{array}$ & 74.5421 & 1.1495 & 0.2608 & 9.6268 & 1.4263 & 0.1657 & 38.3393 & 1.765 & $0.089^{* * *}$ \\
\hline $\begin{array}{c}\text { Average treatment } \\
\text { stock price }\end{array}$ & 113.56 & 3.8903 & $0.0006^{* * *}$ & 12.67 & 4.1695 & $0.0003 * * *$ & 43.69 & 4.4682 & $0.0001 *$ \\
\hline Adjusted R-Square & & 0.8412 & & & 0.9018 & & & 0.949 \\
\hline P-Value for F-test & & $4.86 \mathrm{E}-10$ & & & $1.09 \mathrm{E}-12$ & & & $2.39 \mathrm{E}-16$ \\
\hline
\end{tabular}

Notes: $* 1 \%$ significance, $* * 5 \%$ significance, and $* * * 10 \%$ significance. 
Table 5. Model 2 Regression Outcomes

\begin{tabular}{|c|c|c|c|c|c|c|c|c|c|}
\cline { 2 - 10 } \multicolumn{1}{c|}{} & \multicolumn{3}{c|}{ DoW } & \multicolumn{3}{c|}{ S\&P } & \multicolumn{3}{c|}{ NASDAQ } \\
\hline & $\begin{array}{c}\text { Co- } \\
\text { efficients }\end{array}$ & $\boldsymbol{t}$ Stat & $\boldsymbol{P}$-value & $\begin{array}{c}\text { Co- } \\
\text { efficients }\end{array}$ & $\boldsymbol{t}$ Stat & P-value & $\begin{array}{c}\text { Co- } \\
\text { efficients }\end{array}$ & t Stat & P-value \\
\hline Intercept & 2383.254 & 0.4413 & 0.6624 & 350.558 & 0.5721 & 0.5719 & -381.68 & -0.161 & 0.8733 \\
\hline $\begin{array}{c}\text { US Weekly New } \\
\text { Infections }\end{array}$ & -0.003 & -0.996 & 0.3275 & -0.0001 & -0.359 & 0.7225 & 0.0008 & 0.6322 & 0.5324 \\
\hline $\begin{array}{c}\text { US Weekly New } \\
\text { Deaths }\end{array}$ & 0.1816 & 1.4898 & 0.1475 & 0.0231 & 1.6681 & 0.1064 & 0.0586 & 1.0957 & 0.2826 \\
\hline $\begin{array}{c}\text { US Weekly jobless } \\
\text { claims }\end{array}$ & -0.0002 & -0.899 & 0.3759 & 0 & -1.431 & 0.1636 & -0.0002 & -1.912 & $0.066^{* * *}$ \\
\hline $\begin{array}{c}\text { US Weekly } \\
\text { Economic Index }\end{array}$ & 34227.02 & 2.13 & $0.0421^{* *}$ & 3617.21 & 1.9838 & $0.057^{* * *}$ & 9268.63 & 1.3135 & 0.1997 \\
\hline $\begin{array}{c}\text { Average Vaccine } \\
\text { Stock Price }\end{array}$ & 56.0706 & 1.7652 & $0.088^{* * *}$ & 27.6303 & 3.2702 & $0.0028^{*}$ & 114.49 & 3.5015 & $0.0016^{*}$ \\
\hline $\begin{array}{c}\text { Average Treatment } \\
\text { Stock Price }\end{array}$ & 221.02 & 2.9684 & $0.0061^{*}$ & 5.6689 & 1.5728 & 0.127 & 15.5896 & 1.1176 & 0.2732 \\
\hline Adjusted R-Square & \multicolumn{3}{|c|}{0.7243} & & & 0.7973 & & & 0.8479 \\
\hline P-Value for F-test & $7.21 \mathrm{E}-08$ & & & $1.12 \mathrm{E}-09$ & & $2.19 \mathrm{E}-11$ \\
\hline
\end{tabular}

Notes: * $1 \%$ significance, ${ }^{* *} 5 \%$ significance, and $* * * 10 \%$ significance.

\section{The Regression Results}

Two separate models are run. The first one includes eight Independent Variables-- US Weekly New Infections, US Weekly New Deaths, Global Weekly New Infections, Global Weekly New Deaths, US Weekly Jobless Claims, US Weekly Economic Index, and Average Weekly Stock Prices of the five vaccine firms, and Average Weekly Stock Prices of five COVID-19 treatment medical firms. The second model only has six US variables by excluding the global infections and deaths. The Independent Variable-DoW, S\&P or NASDAQ is used separately in each model.

The following are the outcomes from these two models. The total (cumulative) infections and deaths in the US and world are not included in the regressions since the preliminary studies show that they are not significant and because of the concern of its multicollinarity with other COVID-19 variables.

The above tables show that for the DoW, the Weekly Economic Index is 1\% significant on Model 1 and 5\% significant on Model 2; the Average Price of five vaccine stocks is significant with $10 \%$ on Model 2 but not significant on Model 1; and the Average Price of five COVID treatment stocks is significant at $10 \%$ on Model 1 and $1 \%$ on Model 2. For the S\&P 500, in Model 1, the only significant factor is the Average Price of five COVID treatment stocks (significant at 10\%); however, in Model 2, both the US Weekly Economic Index and Average Price of five vaccine stocks are significant. For the NASDAQ, the Weekly Jobless Claims is significant on Model 2 and the Economic Index is significant on Model 1 ; and the Average Price of five vaccine stocks is significant on both models.

On Table 4 (Model 1), although the coefficient of the Weekly Jobless Claims is positive, not as expected, it is insignificant; therefore, it does not matter. Similarly, in Table 5 (Model 2), the coefficient of the US Weekly New Deaths is positive, different from what is expected, but it is insignificant as well.

From these two models, one can conclude that it is not the infections or deaths in the US that directly and significantly affect the stock indices, but the vaccines and treatment medicine developments decide the stock markets changes. In addition, the Jobless Claims and Weekly Economic Index significantly affected some stock indices (not all three).

As discussed before, the approach used in this study is quite different from the other studies of the COVID-19 and stock markets. This study has two types of control variables-the economy (jobless claims and economic index) and medical developments (vaccines and treatments) since it uses the weekly data and so these control variables are available while other mentioned ones used the daily data. Therefore, the outcomes of this research are not directly comparable with the others.

\section{Implications and Discussions}

COVID-19 did cause the crash of US stock markets in March 2020. But the markets have recovered quickly and all major stock indices reached its historic highs many times since then. Based on this study, the main forces pushing such unprecedented changes are the investors' confidence and optimism on the pandemic control with the vaccines and treatment medicines and their confidence and optimism on the rapid economic recovery. Now more than $50 \%$ of the Americans have been vaccinated and COVID-19 has been under control. What will be the prospects of the US stock markets? There are many factors that will affect and decide the future stock market 
changes.

The first is the continuous decrease of the infections and deaths from the pandemic not only in the US but also in the world. The US is an open economy; trade and international normal travelling are important to its many industries and whole economy. Secondly, the variant virus are the serious threats. Whether such COVID variants can be well controlled and prevented by vaccines will be crucial to the return to the normal lives in the US and world. Thirdly, how soon the US economy can resume to the pre-pandemic level and continues its growth.

Also, there are other factors determining the future development of the stock markets. One is the inflation rate. The US and world are facing steady rising inflations that threaten the economic growth. Another is the government debts. The US federal government's cumulative debts are over $\$ 28$ trillion. Many countries in the world are having the same problems (Chen [8], [9]). The third factor is the corporate profits and earnings. The current stock prices are based on the forecasts of the relevant firms and industries' future profits and earnings. If their actual performances in the future are much worse than projected, the whole stock markets may again crash. Especially, the major indices are now more and much dominated by few big firms, these indices will suffer dramatically if some of these firms have any big trouble. For example, super-large tech companies are under congressional investigations for its monopoly practices and there are proposals to break up tech giants.

The long-term threat to the US economy and so its financial markets is the income gaps among the rich and poor people. According to data from the Organization for Economic Cooperation and Development (OECD), the US has the highest income inequality among all the G7 nations, and in 2017, the US had a Gini coefficient of 0.434 while in the other G7 nations, the Gini ranged from 0.326 in France to 0.392 in the UK. The top 5\% of the US households - those with incomes of at least $\$ 248,729$ in 2018 shared all U.S. income rose from $16 \%$ in 1968 to $23 \%$ in 2018 .

The Wall Street and main street are growingly separated. Increases of profits of corporations and especially stock prices, so its values of the corporations do not benefit ordinary people but have contributed to the wealth increases of these owners/investors, executives and senior employees of the companies dramatically. The inequality not only relates with the social fairness and social stability, but also affects the total markets demand for products/services and economic growth in the future. The two-thirds of the US GDP are made by the consumers directly. Thus, the US economy and its stock markets fully rely on the consumers incomes and its spending.

\section{Conclusion}

This paper studies what have led to the dramatic coming back of the US stock markets. It uses the weekly data of three types of independent variables-the COVID infections and deaths, virus vaccines and therapies, and two economic variables to examine which factors have affected the significant changes of the US stock market indices(dependent variable). The regression outcomes show that it is not the infections or deaths that directly and significantly affect the stock indices, but the vaccines and treatment medicine developments that decide the stock markets movements. In addition, the Jobless Claims and Weekly Economic Index meaningfully impacted some stock indices.

Although the infections or deaths do not directly and significantly change the US stock indices, they could affect other variables such as the jobless claims and weekly economic index and that in turn influence the stocks as the regression outcomes in this study indicated. In other words, there are indirect effects. Also, in the past, the vaccines and therapies of COVID-19 meaningfully impacted the stocks, but such effects are already included in the current stock prices; therefore, the future stock movements will need to depend on other factors, except these medical related ones.

Investors' confidence and optimism on the pandemic control and economic recovery have helped push the recovery of stock markets and its continuous rises. But investors need to be more careful from now on since there are uncertainty and additional risks in the future as discussed on the previous section. The government stimulus plans and Federal Reserve's policies have helped stabilize the economy and financial markets and even led to constant growth of the stock markets. However, such interventions and its positive impacts on the financial markets are limited, given the current, huge cumulative government debts and high inflation. In fact, the opposite may be true in the near future - the government no longer has the financial ability to stimulate the economy and Federal Reserve starts taking actions to raise the interest rates. Then, one may witness another stock market crash, no matter it is short-term and long-term.

As mentioned on Introduction, using the weekly data in this study has its advantages, but it also has its disadvantage-fewer samples of the data, compared with the daily data. This study only focuses on the US data. Similar studies can be conducted based on the data from other economies to see whether relevant results are consistent. Furthermore, it may be interesting to conduct a similar study of the US data from January, 2021 to now, to examine whether there will be the same outcomes as concluded from this paper.

\section{Acknowledgements}

The authors want to appreciate the University of the West for its valuable support to the research project 
leading to this article and the anonymous referees for the valuable comments and suggestions.

Data sources: US infections and deaths from https://github.com/nytimes/covid-19-data; global infections and deaths from https://covid19.who.int; US Weekly New Jobless Claims from https://oui.doleta.gov/unemploy/claims.asp; Weekly Economic Index from https://fred.stlouisfed.org/series/WEI; and US stock indices data from http://Yahoo.com/finance.

\section{REFERENCES}

[1] Ashraf, Badar Nadeem, "Economic impact of government interventions during the COVID-19 pandemic: International evidence from financial markets," Journal of Behavioral and Experimental Finance, pp.100371, 2020. DOI: $10.1016 /$ j.jbef.2020.100371

[2] Akhtaruzzaman, Md, Sabri Boubaker, and AhmetSensoy, "Financial contagion during COVID-19 crisis," Finance Research Letters, vol. 38, pp.100371, 2020. DOI: 10.2139/ssrn.3584898

[3] Baig Ahmed S., Hassan Anjum Butt, Omair Haroon, and Syed Aun R. Rizvia, "Deaths, panic, lockdowns and US equity markets: the case of COVID-19 pandemic," Finance Research Letters, vol.38, pp.100371, 2020. DOI: 10.1016/j.frl.2020.101701

[4] Baker, Scott R, Nicholas Bloom, Steven J Davis, Kyle Kost, Marco Sammon, and Tasaneeya Viratyosin, "The Unprecedented stock market reaction to COVID-19," The Review of Asset Pricing Studies, vol. 10, no.4, 2020, Pages 742-758, DOI: 10.1093/rapstu/raaa008

[5] Banerji, Gunjan, "Why did stock markets rebound From Covid in record Time? Here are five reasons", Wall Streel Journal, 2020

[6] Barry, John M., The Great influenza: the story of the deadliest pandemic in history, Viking Press, 2004

[7] Berk, Cem Berk and Bekir Tutarli, "Dead or alive: Modern portfolio theory based on financial analysis", Universal Journal of Accounting and Finance, Vol. 8(4), pp. 83 - 91, 2020. DOI: 10.13189/ujaf.2020.080401

[8] Chen, Yueyun(Bill), "The Business cycle and economic Crisis - when will China experience them?", Journal of Advances in Economics and Finance, vol. 4, no. 2, 2019, pp60-78; DOI:10.22606/jaef.2019.42003

[9] Chen, Yueyun(Bill), Xingong Li, Chengyi Pu, and Lianlian Lin, "The Relationship of the manufacturing growth with the financial industry and real estate industry," Journal of Business and Economic Policy, vol. 6, no. 2, 2019, pp38-47; DOI: $10.30845 /$ jbep

[10] Chahuán-Jiménez, Karime, Rolando Rubilar, Hanns de la Fuente-Mella, and Víctor Leiva "Breakpoint analysis for the COVID-19 pandemic and its effect on the stock markets," Entropy, vol. 23, no.1, 2021, pp1-12; DOI: $10.3390 / \mathrm{e} 23010100$
[11] Congressional Budget Office(CBO), "A potential influenza pandemic: possible macroeconomic effects and policy issues," Washington DC: Congressional Budget Office, 2005

[12] David, S.A., C M C Inácio Jr., José A Tenreiro Machado, "The Recovery of global stock markets indices after impacts due to pandemics," Research in International Business and Finance, vol. 55, p. 101335, 2021, DOI: 10.1016/j.ribaf.2020.101335

[13] Gherghina, Stefan Cristian, and Liliana Nicoleta Simionescu, "Exploring the co-movements between stock market returns and COVID 19 pandemic: evidence from wavelet coherence analysis," Allied Economic Letter, 2021, DOI: $10.1080 / 13504851.2021 .1937034$

[14] Hai, Wen, Zhong Zhao, Jian Wang, and Zhen-Gang Hou, "The Short-term impact of SARS on the Chinese economy," Asian Economic Papers, vol. 3, no. 1, pp 57-61, 2004, DOI: $10.1162 / 1535351041747905$

[15] Harjoto, Maretno Agus, Fabrizio Rossi, and Robert Lee, and Bruno S.Sergi "How do equity markets react to COVID-19? Evidence from emerging and developed countries," Journal of Economics and Business, vol. 115, pp 105966, 2021, DOI: 10.1016/j.jeconbus.2020.105966

[16] Haryanto, A. Mulyo and Wisnu Mawardi, "Impact of COVID-19 News on Performance of Indonesia Stock Market", Universal Journal of Accounting and Finance, Vol. 9(2), pp. 226 - 231, 2021. DOI: 10.13189/ujaf.2021.090212

[17] Hasan, Md. Bokhtiar, Masnun Mahi, Tapan Sarker, and Md Ruhul Amin, "Spillovers of the COVID-19 pandemic: impact on global economic activity, the stock market, and the energy sector," Journal of Risk and Financial Management, vol.14, no. 5, 2021, pp1-18; DOI: $10.3390 / \mathrm{jrfm} 14050200$

[18] Lee, Jong-Wha, and Warwick J. McKibbin, "Globalization and disease: the case of SARS," Asian Economic Papers, vol.3, no. 1,pp 113-131, 2004, DOI:10.1162/15353510417 47932

[19] McKibbin, Warwick, and Roshen Fernando, "The global macroeconomic impacts of COVID-19: Seven scenario,", vol. 20, no. 2, pp 1-30, 2021, DOI: 10.1162/asep_a_00796

[20] Salisu, Afees A.,Abdulsalam Abidemi Sikiru, Xuan VinhVo, "Pandemics and the emerging stock markets," Borsa Istanbul Review, vol. 20, pp. S40-S48, 2020, DOI: 10.1016/j.bir.2020.11.004

[21] Siu, Alan, and Y. C. Richard Wong, "Economic impact of SARS: the case of Hong Kong," Asian Economic Papers, vol. 3, no. 1, pp. 62-83, 2004, DOI: 10.1162/153535104174 7996

[22] Sharma, Gagan Deep, Aviral Kumar Tiwari, Mansi Jain, Anshita Yadav, and BurakErkut "Unconditional and conditional analysis between covid-19 cases, temperature, exchange rate and stock markets using wavelet coherence and wavelet partial coherence approaches," Heliyon, vol. 7, no. 2, pp. 06181, 2021, DOI: 10.1016/j.heliyon.2021.e061 81

[23] Shannon, Gary W. and Jason Willoughby, "Severe acute 
respiratory syndrome (SARS) in Asia: a medical geographic perspective", Eurasian Geography and Economics, vol. 45, no. 5, pp.359-381, 2013, DOI: $10.2747 / 1538-7216.45 .5 .359$

[24] Viscusi, W., Jahn Hakes, and Alan Carlin, "Measures of mortality risks", Journal of Risk and Uncertainty, vol. 14, pp. 213-233, 1997, DOI: 10.1023/A:1007799508646

[25] Yildirim, Ecenur UĞURLU, "The impact of COVID-19 pandemic on the financial contagion among Turkey, US, and China stock markets," Işsletme Araştırmaları Dergisi, vol. 2, no.3, pp. 2764-2773, 2020, DOI:10.20491/isarder.2 020.1006

[26] Zhang, Dayong, Min Hua, Qiang Ji, "Financial markets under the global pandemic of COVID-19," Finance Research Letters, vol. 36, pp.101528, 2020, DOI: 10.1016/j.frl.2020.101528 